\title{
Glucose intolerance during diuretic therapy in elderly hypertensive patients. A second report from the European Working Party on high blood pressure in the elderly (EWPHE)
}

\author{
A. Amery ${ }^{1}$, W. Birkenhäger ${ }^{2}$, P. Brixko ${ }^{3}$, C. Bulpitt ${ }^{4}$, D. Clement $^{5}$, M. Deruyttere $^{6}$,

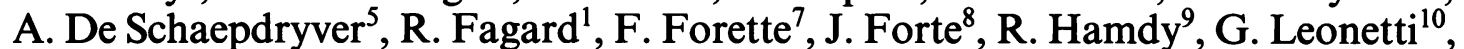 \\ K. O'Malley ${ }^{11}$, M. Murphy ${ }^{4}$, J. Petrie ${ }^{12}$, J. Tuomilehto ${ }^{13}$, J. Webster ${ }^{12}$, B. Williams ${ }^{14}$.
}

\begin{abstract}
Summary: Five hundred and seven elderly hypertensive patients were followed for 1 year, 371 for 2 years and 270 for 3 years in a double-blind, randomized, controlled trial in which they received either placebo or 25-50 mg hydrochlorothiazide and 50-100 mg of triamterene daily. One third of the active treatment group also received $250 \mathrm{mg}$ to $2 \mathrm{~g}$ methyldopa daily. After 1 year the active treatment group had an average increase in fasting blood sugar of $2.5 \mathrm{mg} / \mathrm{dl}$ compared with an average fall of $1.4 \mathrm{mg} / \mathrm{dl}$ in the placebo group $(P=0.01)$. The increase in blood sugar 1 hour and 2 hours after $50 \mathrm{~g}$ oral glucose tended to be greater in the actively treated group but these increases did not achieve statistical significance. The effects of diuretic treatment were established after one year and did not increase further over the next 2 years. Overall there was an increase in fasting blood sugar of $5 \mathrm{mg} / \mathrm{dl}$ in the active treatment group which occurred mainly in the first year.

The hyperglycaemic effect of diuretics appeared to be partly or wholly related to potassium loss since, in both groups, impairment of glucose tolerance was most marked in those in whom serum potassium decreased. The measures of blood sugar were also positively related to systolic pressure before and after treatment.
\end{abstract}

The following centres collaborate in the EWPHE trial:

1 University Hospital Gasthuisberg, Leuven, Belgium: R. Fagard, J. Hellemans $\dagger$, W. Pelemans.

2 Zuiderziekenhuis, Rotterdam, The Netherlands: W. Birkenhäger, P. de Leeuw, P. Willemse, N. Vogel.

3 Geriatric Hospital Le Valdor, Liège, Belgium: P. Brixko, A. Ernould, A. Mutsers.

4 Hammersmith Hospital, London, England: C.J. Bulpitt, P. Lewis, M. Murphy.

5 University Hospital, Gent, Belgium: M. Bogaert, D. Clement.

6 Medisch Centrum voor Huisartsen, Leuven, Belgium: M. Deruyttere.

7 Hôpital Bruca, Paris, France: P. Berthaux, F. Forette, J.F. Henry.

8 University Hospital Santa Maria, Lisboa, Portugal: F. de Padua, J. Forte, J.M. Pereira-Miguel.

9 St John's Hospital, London, England: R.C. Hamdy, N.H. Perera.

Correspondence: C.J. Bulpitt, M.Sc., M.D., F.R.C.P. Department of Epidemiology, London School of Hygiene and Tropical Medicine, Keppel Street, London WC1E 7HT, UK. Accepted: 15 May 1986
10 Centro di Fisiologia Clinica e Ipertensione, Milano, Italy: G. Leonetti. X. Tammaro, L. Terzoli, Z. Zanchetti.

11 Royal College of Surgeons, Dublin, Ireland: M. Laher, P. McCormack, F. Meagher, E. O'Brien, W. O'Callaghan, K. O'Malley.

12 Aberdeen Royal Infirmary, Aberdeen, Scotland: J.C. Petrie, J. Webster.

13 North Karelia Project, Helsinki, Finland: A. Alasoini, A. Koistinen, A. Nissinen, P. Puska, J. Tuomilehto.

14 Victoria Geriatric Unit, Glasgow, Scotland: K. Beard, J.P.R. MacFarlane†, B.O. Williams.

The EWPHE trial was coordinated by A. Amery, Leuven and A. De Schaepdryver, Gent, Belgium.

The Steering Committee included A. Amery, A. De Schaepdryver, C. Dollery, J.V. Joossens and T. Strasser.

We are also indebted to $R$. Grauwels, who was in charge of the statistical analysis and also to K. Byttebier, R. Deruyck, M. Stinissen and V. Mariën for their technical assistance.

The trial was supervised by W.H.O. and supported by the Belgian National Research Foundation (N.F.W.O.) and the Belgian Hypertension Committee through grants of Merck, Sharp \& Dohme and Smith Kline \& French.

(C) The Fellowship of Postgraduate Medicine, 1986 


\section{Introduction}

A high proportion of hypertensive patients on thiazide diuretics have an abnormal glucose tolerance (Breckenridge et al., 1967) and case reports show that diabetes mellitus can be precipitated in susceptible subjects (Wilkins, 1959; Schwab et al., 1963). However, the magnitude of this problem remained in doubt until it was shown that blood sugar is increased in young patients treated for more than 5 years (Lewis et al., 1976; Murphy et al., 1982). The European Working Party on Hypertension in the Elderly (Amery et al., 1978) reported that fasting blood sugar increased by $10 \mathrm{mg} / 100 \mathrm{ml}$ over 2 years in elderly hypertensive patients given a combined capsule of hydrochlorothiazide and triamterene. This report was based on the results in the first 119 patients to be followed in this randomized double-blind placebo controlled trial. The article generated some disagreement and discussion (Berglund \& Andersson, 1981). The present report presents the results on over 500 patients entered into the trial. The degree of glucose intolerance is reported with more precision and the mechanisms underlying these changes are discussed in greater depth.

\section{Patients and methods}

The European Working Party on Hypertension in the Elderly (EWPHE) has conducted a double-blind, randomized trial of the effect of treating hypertension in persons aged over 60 (Amery et al., 1985).

By December 1983, 853 patients, average age 72 (range 60-97) had entered the multicentre study, 69\% were women. Five hundred and forty-two had a fasting blood sugar recorded initially and one or more years later. Of these, $16(3 \%)$ received oral hypoglycaemic drugs before a glucose estimation and were excluded from the analyses. Eight of these patients were in the actively treated group and eight in the placebo group. Diabetics receiving insulin were excluded from entry to the trial. Five hundred and seven patients had fasting blood sugars at entry and one year, 371 at entry and 2 years, and 270 at 3 years. Three hundred and eighty-six patients $(71 \%)$ also had blood glucose estimations made 1 and 2 hours after taking $50 \mathrm{~g}$ glucose.

We calculated (a) the change in fasting, 1-hour, and 2-hour blood sugars after 1,2 and 3 years, and (b) the sum of the fasting, 1-hour and 2-hour blood sugar as a measure of the 'area' under the glucose tolerance curve.

The measures of glucose tolerance were compared between the placebo and diuretic groups by the Student's $t$-test. Multiple regression techniques were used in order to determine whether the effects of treatment were independent of, or related to, other variables.

\section{Results}

Table I gives the increases in fasting blood sugar, and blood sugars 60 and 120 minutes after the glucose load from baseline and after 1,2 and 3 years. In the placebo group small increases of 4 and $0.6 \mathrm{mg} / 100 \mathrm{ml}$ in fasting blood sugar were observed during the second and third year in the trial. These rises followed a fall of 1.4/ $100 \mathrm{ml}$ in the first year. In contrast, for actively treated patients receiving a diuretic, the average fasting blood sugar rose by about $3 \mathrm{mg} / 100 \mathrm{ml}$ for every year in the

Table I The increase in fasting blood sugar (FBS) in $\mathrm{mg} / 100 \mathrm{ml}$, blood sugar sixty minutes after $50 \mathrm{~g}$ glucose (60' BS) and 120 minutes after (120' BS): for 3 years after entry to the trial and for the placebo and actively treated group separately.

\begin{tabular}{|c|c|c|c|c|c|c|c|c|c|}
\hline & \multicolumn{3}{|c|}{1 year } & \multicolumn{3}{|c|}{2 years } & \multicolumn{3}{|c|}{3 years } \\
\hline & $F B S$ & $60^{\prime} B S$ & $120^{\prime} B S$ & $F B S$ & $60^{\prime} B S$ & $120^{\prime} B S$ & $F B S$ & $60^{\prime} B S$ & $120^{\prime} B S$ \\
\hline \multicolumn{10}{|l|}{ Placebo } \\
\hline Average & -1.35 & -6.00 & +2.25 & +2.43 & -5.95 & +3.76 & +3.01 & -0.97 & +8.49 \\
\hline SE & 1.12 & 3.22 & 2.73 & 1.60 & 3.27 & 3.10 & 1.77 & 4.33 & 4.72 \\
\hline $\mathbf{n}$ & 253 & 178 & 170 & 188 & 123 & 124 & 141 & 87 & 82 \\
\hline \multicolumn{10}{|l|}{ Active } \\
\hline Average & +2.56 & -1.09 & +2.98 & +7.13 & +4.27 & +10.28 & +9.74 & +7.10 & +12.72 \\
\hline SE & 1.12 & 3.23 & 3.23 & 1.38 & 4.30 & 3.98 & 1.86 & 5.39 & 6.41 \\
\hline $\mathbf{n}$ & 254 & 175 & 165 & 183 & 113 & 116 & 129 & 80 & 74 \\
\hline Difference* & $\begin{array}{c}+3.91 \\
P=0.01\end{array}$ & $\begin{array}{c}+4.91 \\
\text { NS }\end{array}$ & $\begin{array}{c}+0.73 \\
\text { NS }\end{array}$ & $\begin{array}{c}+4.70 \\
P<0.05\end{array}$ & $\begin{array}{c}+10.22 \\
P=0.06\end{array}$ & $\begin{array}{l}+6.52 \\
\text { NS }\end{array}$ & $\begin{array}{c}+6.73 \\
P<0.01\end{array}$ & $\begin{array}{c}+8.07 \\
\text { NS }\end{array}$ & $\begin{array}{l}+4.23 \\
\text { NS }\end{array}$ \\
\hline
\end{tabular}

*Active - placebo.

NS = not significant 


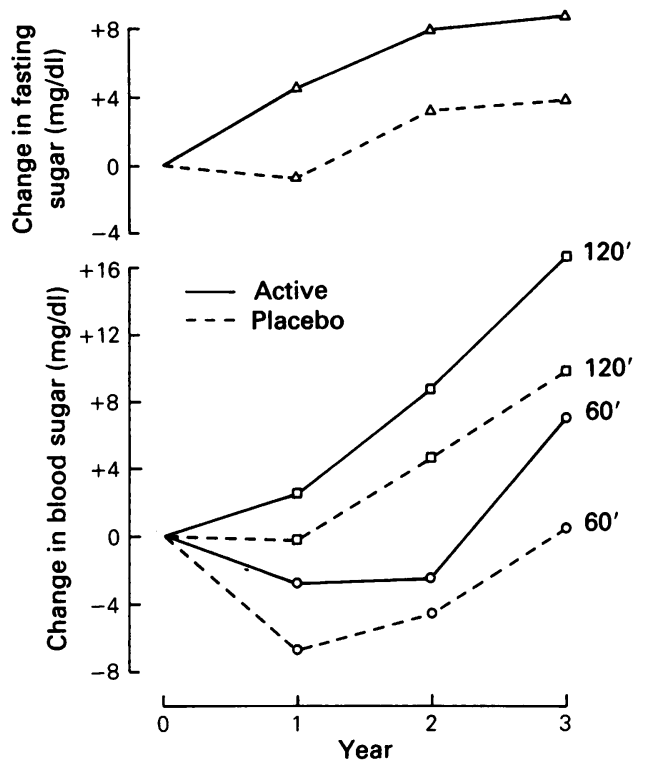

Figure 1 Change in fasting, 60 minute and 120 minute blood sugar in 243 patients (128 placebo, 115 active group) with fasting blood sugar measured initially and after 1,2 and 3 years of follow-up. Sixty and 120 minute blood sugars measured on each occasion in 134 patients (74 placebo and 60 active group). trial. The differences between the two groups in fasting blood sugar were statistically significant after 1 $(P<0.05), 2(P<0.05)$ and $3(P<0.01)$ years.

The average blood sugar 60 minutes after the glucose load fell $6 \mathrm{mg} / 100 \mathrm{ml}$ during the first year in the placebo group but returned almost to baseline after 3 years. In contrast, in the actively treated group the average 60 minutes glucose increased after 2 years and, at this stage, had increased by $10 \mathrm{mg} / 100 \mathrm{ml}$ more than in the placebo group $(P=0.06)$.

The average 120 minutes glucose increased by $2-3 \mathrm{mg} / 100 \mathrm{ml} / \mathrm{year}$ in the placebo group and about $4 \mathrm{mg} / 100 \mathrm{ml}$ in the actively treated group. These increases did not differ significantly from one another. In the actively treated group the average fasting blood sugar increased by $3 \mathrm{mg} / 100 \mathrm{ml} / \mathrm{year}$ in both men and women and both ages 60-69 and 70-79.

Figure 1 gives the results for a cohort of 243 patients who had a fasting blood sugar measured initially and after 1, 2 and 3 years of follow-up. These withinsubject data show that a $5 \mathrm{mg} / \mathrm{dl}$ difference in fasting blood sugar between the groups was established after 1 year and was constant thereafter. Similarly, any difference in 60 minute and 120 minute blood sugar averaged about $5 \mathrm{mg} / \mathrm{dl}$ and was established by one year.

Table II shows the absolute concentrations of blood sugar according to whether the patients were receiv-

Table II Average fasting blood sugar (BS), 60 minutes blood sugar, 120 minutes blood sugar and area under the curve, initially and after 1, 2 and 3 years, subdivided according to treatment: no active diuretic, one or two active diuretic capsules only, and 2 active diuretics plus methyldopa.

\begin{tabular}{|c|c|c|c|c|c|c|}
\hline & & Placebo & $\begin{array}{c}\text { Active } \\
1 \text { diuretic }\end{array}$ & $\begin{array}{c}\text { Active } \\
2 \text { diuretics }\end{array}$ & $\begin{array}{c}\text { Active } \\
\text { Methyldopa }+ \\
2 \text { diuretics }\end{array}$ & $\begin{array}{c}\text { All } \\
\text { active }\end{array}$ \\
\hline $\begin{array}{l}\text { Fasting BS } \\
(\mathrm{mg} / 100 \mathrm{ml})\end{array}$ & $\begin{array}{l}\text { Initial } \\
1 \text { year } \\
2 \text { year } \\
3 \text { year }\end{array}$ & $\begin{array}{l}92.1 \\
88.8 \\
91.5 \\
91.1\end{array}$ & $\begin{array}{l}91.1 \\
92.5 \\
93.2\end{array}$ & $\begin{array}{l}90.1 \\
89.3 \\
94.7\end{array}$ & $\begin{array}{r}95.5 \\
100.6 \\
97.6\end{array}$ & $\begin{array}{l}92.8 \\
91.8 \\
93.5 \\
94.8\end{array}$ \\
\hline $\begin{array}{l}60 \text { minutes BS } \\
(\mathrm{mg} / 100 \mathrm{ml})\end{array}$ & $\begin{array}{l}\text { Initial } \\
1 \text { year } \\
2 \text { year } \\
3 \text { year }\end{array}$ & $\begin{array}{l}156.1 \\
143.4 \\
143.9 \\
149.6\end{array}$ & $\begin{array}{l}138.9 \\
141.5 \\
138.8\end{array}$ & $\begin{array}{l}155.6 \\
152.9 \\
163.6\end{array}$ & $\begin{array}{l}160.4 \\
168.2 \\
171.1\end{array}$ & $\begin{array}{l}157.9 \\
150.0 \\
151.2 \\
155.3\end{array}$ \\
\hline $\begin{array}{l}120 \text { minutes BS } \\
(\mathrm{mg} / 100 \mathrm{ml})\end{array}$ & $\begin{array}{l}\text { Initial } \\
1 \text { year } \\
2 \text { year } \\
3 \text { year }\end{array}$ & $\begin{array}{l}121.0 \\
111.3 \\
111.8 \\
119.1\end{array}$ & $\begin{array}{l}106.1 \\
119.6 \\
117.7\end{array}$ & $\begin{array}{l}118.1 \\
112.6 \\
124.2\end{array}$ & $\begin{array}{l}126.4 \\
133.3 \\
145.2\end{array}$ & $\begin{array}{l}120.9 \\
115.8 \\
122.0 \\
128.9\end{array}$ \\
\hline $\begin{array}{l}\text { Sum } \\
(\mathrm{mg} / 100 \mathrm{ml})\end{array}$ & $\begin{array}{l}\text { Initial } \\
1 \text { year } \\
2 \text { year } \\
3 \text { year }\end{array}$ & $\begin{array}{l}368.2 \\
342.6 \\
342.2 \\
356.3\end{array}$ & $\begin{array}{l}330.7 \\
350.3 \\
346.3\end{array}$ & $\begin{array}{l}364.6 \\
353.5 \\
370.4\end{array}$ & $\begin{array}{l}384.5 \\
383.0 \\
392.4\end{array}$ & $\begin{array}{l}370.6 \\
356.5 \\
358.7 \\
367.3\end{array}$ \\
\hline
\end{tabular}




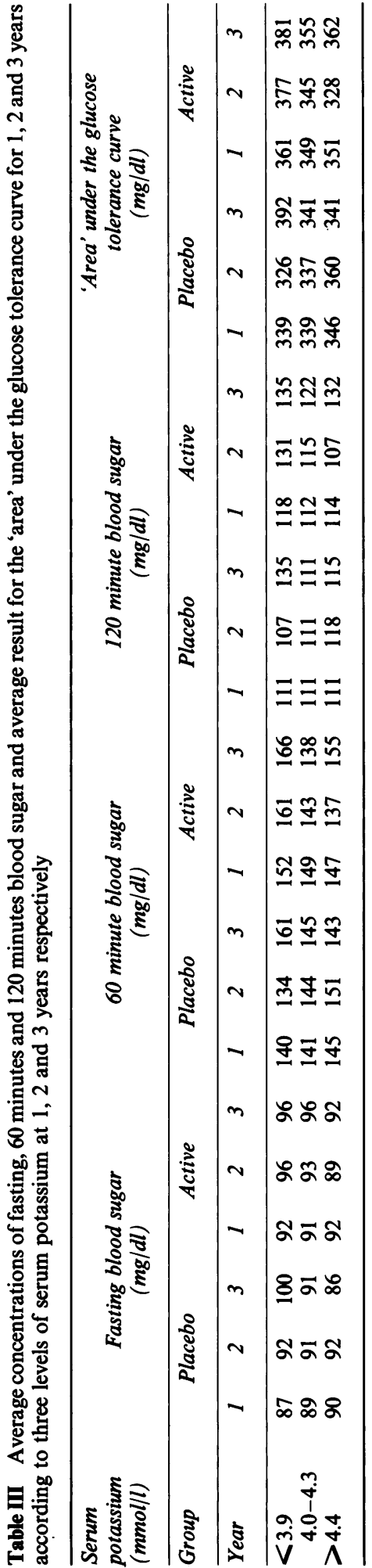

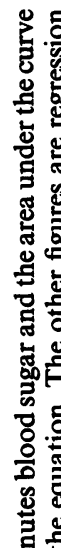

昌起.

तิ ซु

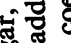

题

8 章

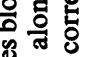

造

晃哥

路

की

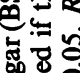

\%

as

ठํㅇㅇ

90

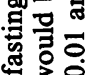

30

最苛

总

逭

잉.

是 홍

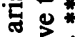

光
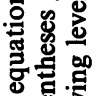

व.

현을

동

氙先

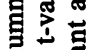

ठे

氙.

$\geq$ 壱

월

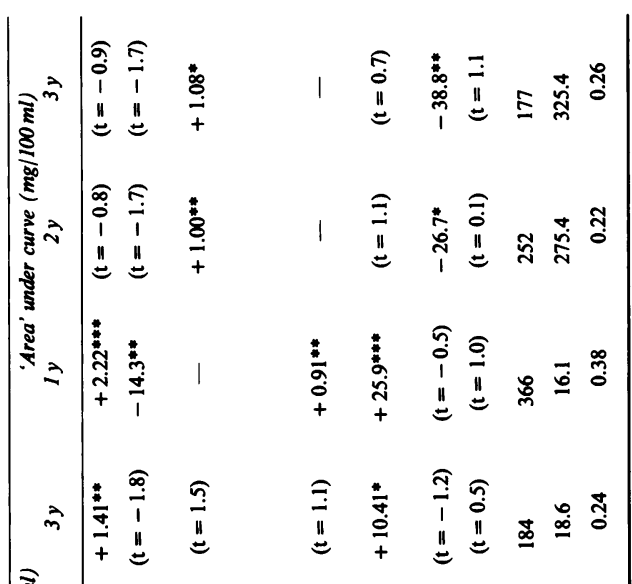

है

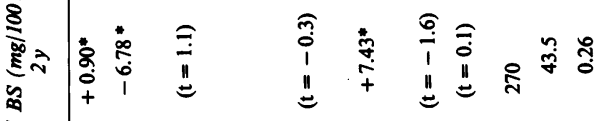

สิ

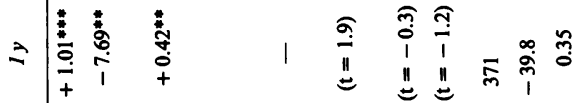

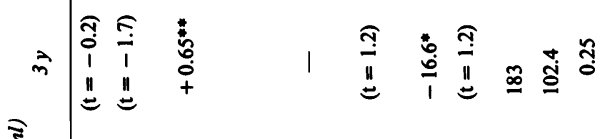

ह

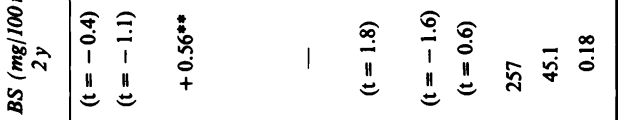

ํㅡㄹ

8

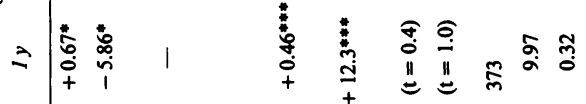

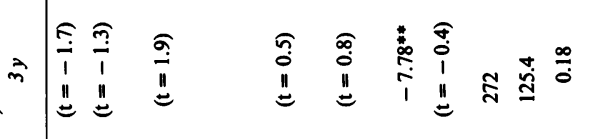

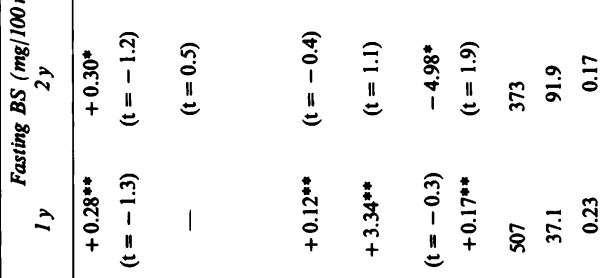

응

음

吾

흘

뭉.

के.

일

옥

을.

N

N

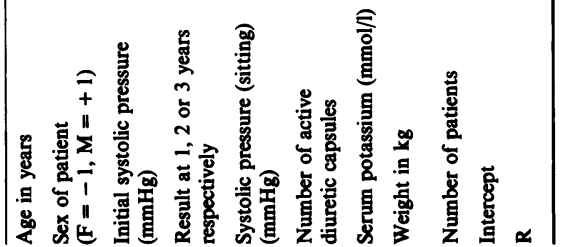


ing, at the end of their observation period: no active treatment, only 1 or 2 active diuretic capsules a day, and 2 active diuretics plus methyldopa. There was a marked tendency for the highest levels of blood sugar to occur in those given both 2 active diuretic capsules and active methyldopa, but this excess was not statistically significant.

Table III reports the blood sugar after 1, 2 and 3 years of follow-up for the treatment group, active or placebo, and for three groups: serum potassium $<3.9 \mathrm{mmol} / 1,4.0-4.3 \mathrm{mmol} / 1$, and $>4.4 \mathrm{mmol} / \mathrm{lafter}$ 1,2 and 3 years of follow-up. The absolute level of fasting blood sugar was negatively correlated with serum potassium, not after 1 year but after 2 years $(r=-0.12, P<0.05)$ and 3 years $(r=-0.18$, $P<0.01)$. The 60 minute blood sugar was also significantly correlated with the concentration of serum potassium after 3 years $(r=-0.16, P<0.05)$. After 2 years the 120 minutes glucose was significantly negatively correlated with the concentration of serum potassium at that time $(r=-0.12, P<0.05)$. The 'area' under the glucose tolerance curve was significantly associated with serum potassium after 2 years $(r=-0.13, P<0.05)$ and 3 years $(r=-0.20$, $P<0.01)$. After 3 years in the trial, the measures of

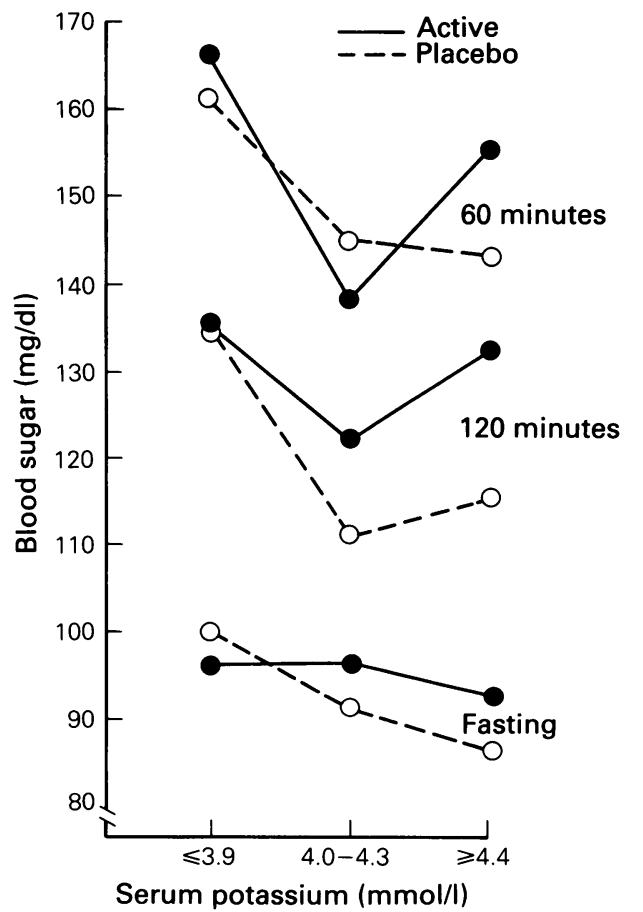

Figure 2 Fasting blood sugar and 60 and 120 minute blood sugar in $\mathrm{mg} / \mathrm{dl}$ at 3 years, according to the concentration of serum potassium and whether the patients were on active or placebo treatment. blood sugar were all significantly and negatively associated with serum potassium at that time. Conversely, the association between these variables 1 year after entry was weak and not statistically significant. Figure 2 illustrates the results after 3 years. The highest fasting, 60 and 120 minute blood sugar concentrations occurred at serum potassium concentrations of $<3.9 \mathrm{mmol} / 1$ and were similar whether the patients received active diuretic treatment or placebo.

Table IV assesses the strength of the associations when many variables are taken into account and gives the equations derived from regressing absolute level of blood sugar on age, sex and initial and achieved systolic pressure, the number of active diuretic capsules, serum potassium and weight. Age was positively, independently, and significantly related to the absolute concentration of blood sugar. Women also tended to have higher blood sugars than men. In the first year, when achieved systolic pressure was high, fasting and 60 minute blood sugars were also increased. Sixty minute blood sugars were higher in the second and third years when the initial systolic pressure was high. Fasting blood sugar was positively related to weight at 1 year. For most measurements of blood sugar either the number of active diuretic capsules prescribed was positively related to blood sugar or the concentration of serum potassium was negatively related to blood sugar.

\section{Discussion}

This second report is in broad agreement with the previous communication (Amery et al., 1978), but there are some important new findings to discuss in consequence of the five-fold increase in the number of patients.

In the first report we described an increase in fasting blood sugar of $4-5 \mathrm{mg} / 100 \mathrm{ml} /$ year with active diuretic treatment, a larger increase when 2 capsules were prescribed than when only one was given. The present report confirms an increase of $5 \mathrm{mg} / 100 \mathrm{ml}$ in this first year, but suggests that in the elderly hypertensive it does not increase at this rate every year. In fact, when considering only those 243 patients followed every year for 3 years, the active-placebo differences were identical after 1, 2 and 3 years respectively. The yearly increases in fasting blood sugar in the placebo group appeared to be due to ageing and the effect of a diuretic was established during the first year of treatment.

The 120 minute blood sugar tended to increase most with time in both the placebo and actively treated groups. This 'ageing' effect averaged $3 \mathrm{mg} / 100 \mathrm{ml} /$ year. Any upward drift in fasting or 60 minute blood sugar appeared to be less marked, but entry to the trial, presumably with changes in dietary habits in some 
patients due to an increased concern for their health, may have distorted any tendency to increase steadily with time.

In the first communication we reported that fasting and 60 minute and 120 minute blood sugars increased most when the serum potassium fell. The present report confirms this finding after 2 and 3 years, but not after 1 year of follow-up, a finding previously reported by Murphy and his colleagues (1982). Most importantly, in the placebo treated group the fasting blood sugar was related to the concentration of serum potassium after 3 years in the trial. The relationship between serum potassium and fasting blood sugar was therefore not due solely to compliance with the active diuretic regimen. The negative association in the placebo group supports the hypothesis that thiazide diuretics raise fasting blood sugar by lowering body or serum potassium.

The positive association between blood sugar and either initial or achieved blood pressure confirms the positive association between blood sugar and hypertension in normotensive individuals (Florey et al., 1976; Stamler et al., 1974). In fact, a $1 \mathrm{mmHg}$ increase

\section{References}

AMERY, A., BERTHAUX, P., BULPITT, C., DERUYTTERE, M., DE SCHAEPDRYVER, A., DOLLERY, C., FAGARD, R., FORETTE, F., HELLEMANS, J., LUND-JOHANSEN, P., MUTSERS, A. \& TUOMILEHTO, J. (1978). Glucose intolerance during diuretic therapy. Results of trial by the European Working Party on Hypertension in the Elderly. Lancet, i, 681.

AMERY, A., BIRKENHAGER, W., BRIXKO, P., BULPITT, C., CLEMENT, D., DERUYTTERE, M., DE SCHAEPDRYVER, A., DOLLERY, C., FAGARD, R., FORETTE, F., FORTE, J., HAMDY, R., HENRY, J.F., JOOSSENS, J.V., LEONETTI, G., LUND-JOHANSEN, P., O'MALLEY, K., PETRIE, J., STRASSER, T., TUOMILEHTO, J. \& WILLIAMS, B. (1985). Mortality and morbidity results from the European Working Party on high blood pressure in the elderly trial. Lancet, i, 1349.

AMERY, A. \& DE SCHAEPDRYVER, A. (1981). Antihypertensive therapy in patients above age 60 . Fifth interim report of the European Working party on high blood pressure in the elderly (EWPHE). Current Concepts in Hypertension and Cardiovascular Disorders, 2, 14.

BERGLUND, G. \& ANDERSSON, A. (1981). Beta blockers or diuretics in hypertension? A six year follow-up of blood pressure and metabolic side-effects. Lancet, $\mathbf{i}, 744$.

BRECKENRIDGE, A., WELBORN, T.A., DOLLERY, C.T. \& FRASER, F. (1967). Glucose tolerance in hypertensive in systolic pressure was associated with a $0.5 \mathrm{mg} /$ $100 \mathrm{ml}$ increase in both 60 minute and 120 minute blood sugars, but only a $0.1 \mathrm{mg} / 100 \mathrm{ml}$ increase in fasting blood sugar. The latter, rather weak, association was partly explained by the $0.2 \mathrm{mg} / 100 \mathrm{ml}$ increase in fasting blood sugar associated with every kilogram increase in weight, weight also being positively associated with blood pressure.

The diuretic treatment used in the EWPHE trial consisted of a combination of potassium losing diuretic, hydrochlorothiazide, and a potassium sparing diuretic triamterene. The fall in serum potassium in the trial averaged only $0.2 \mathrm{mmol} / 1$ (Amery \& de Schaepdryver, 1981) and it is possible that a larger decrease in serum potassium would have led to a more serious deterioration in glucose tolerance than that observed in the trial. In the Medical Research Council Trial on mild hypertension (1981) the fall in serum potassium in comparison to placebo averaged $0.6 \mathrm{mmol} / 1$ when only a potassium losing diuretic was employed. Also, the effects on glucose tolerance were not cumulative in the EWPHE trial.

patients on long-term diuretic therapy. Lancet, i, 61 .

FLOREY, C. DU V., UPPAL, S. \& LOWY, C. (1976). Relation between blood pressure, weight and plasma sugar and serum insulin levels in schoolchildren aged 9-12 years in Westhend, Holland. British Medical Journal, i, 1368.

LEWIS, P.J., KOHNER, E.M., PETRIE, A. \& DOLLERY, C.T. (1976). Deterioration of glucose tolerance in hypertensive patients on prolonged diuretic treatment. Lancet, i, 564.

MEDICAL RESEARCH COUNCIL WORKING PARTY ON MILD TO MODERATE HYPERTENSION (1981). Adverse reactions to bendrofluazide and propranolol for the treatment of mild hypertension. Lancet, ii, 593.

MURPHY, M.B., LEWIS, P.J., KOHNER, E., SCHUMER, B. \& DOLLERY, C.T. (1982). Glucose intolerance in hypertensive patients treated with diuretics; a fourteen-year followup. Lancet, ii, 1293.

SCHWAB, R.H., PERLOFF, J.K. \& PORUS, R.L. (1963). Chlorothiazide-induced gout and diabetes. Archives of Internal Medicine, 111, 465.

STAMLER, J., RHONBERG, P., BERKSON, D.M., SCHOENBERGER, J.A., SHEKELLE, R.B., DYER, A., STAMLER, R., SHEKELLE, S., REEDUS, W. \& WANNAMAKER, J. (1974). Relationship of multiple variables to blood pressure. Circulation, 50 (suppl), 147.

WILKINS, R.W. (1959). New drugs for the treatment of hypertension. Annals of Internal Medicine, 50, 1. 